\title{
Vincristine induces cell cycle arrest and apoptosis in SH-SY5Y human neuroblastoma cells
}

\author{
YUE TU $^{1 *}$, SHIXIANG CHENG ${ }^{1 *}$, SAI ZHANG ${ }^{1}$, HONGTAO SUN $^{1}$ and ZHONGWEI XU ${ }^{2}$ \\ ${ }^{1}$ Institute of Traumatic Brain Injury and Neurological Diseases, Center for Neurology and Neurosurgery, Pingjin Hospital \\ and ${ }^{2}$ Department of Cell Biology, Medical College of Chinese Armed Police Forces, Tianjin 300162, P.R. China
}

Received July 13, 2012; Accepted September 20, 2012

DOI: $10.3892 /$ ijmm.2012.1167

\begin{abstract}
Neuroblastoma is a common childhood tumor. Vincristine (VCR), an alkaloid extracted from Catharanthus roseus, is commonly used in combination chemotherapy. However, the mechanisms of VCR-induced neuroblastoma cell death are not clear. The aim of this study was to investigate the impact of VCR on mitosis and apoptosis of SH-SY5Y neuroblastoma cells and the underlying mechanisms. SH-SY5Y cells were treated with increasing VCR doses for different time points. Cell proliferation was detected using the MTT assay. Mitotic rate was quantified by immunofluorescence. Cell cycle and apoptosis were analyzed by flow cytometry. The mRNA and protein expression of caspase-3 and -9 (apoptotic factors), as well as cyclin B and D (cell cycle factors), was evaluated by real-time (RT)-PCR and western blot analysis, respectively. VCR inhibited SH-SY5Y cell proliferation in a time- and dose-dependent manner $(\mathrm{P}<0.05)$. The $\mathrm{IC}_{50}$ of $\mathrm{VCR}$ in SH-SY5Y cells was determined as $0.1 \mu \mathrm{M}$. VCR at $0.1 \mu \mathrm{M}$ induced mitotic arrest and apoptosis, promoted the expression of caspase- 3 and -9 and cyclin $\mathrm{B}$, while decreasing the expression of cyclin D at 6, 12, 18 and $24 \mathrm{~h}$. Except for the mRNA expression of cyclin D at $6 \mathrm{~h}$, these changes were significant at both the mRNA and protein levels $(\mathrm{P}<0.05)$. VCR induces mitotic arrest of SH-SY5Y cells by regulating cyclin B and D. It further induces apoptosis in these cells through the activation of caspase-3 and -9 . This study provides fundamental evidence for the application of VCR in neuroblastoma chemotherapy.
\end{abstract}

\section{Introduction}

Neuroblastoma is a type of solid tumor that commonly occurs in children under 5 years of age, with a current prevalence of

Correspondence to: Dr Sai Zhang, Institute of Traumatic Brain Injury and Neurological Diseases, Center for Neurology and Neurosurgery, Pingjin Hospital, Medical College of Chinese Armed Police Forces, Tianjin 300162, P.R. China

E-mail: zhangsai718@yahoo.com

${ }^{*}$ Contibuted equally

Key words: vincristine, cell cycle arrest, apoptosis, neuroblastoma, SH-SY5Y cells
1 out of 100,000 children (1). The clinical hallmark of neuroblastoma is its heterogeneity (2). It most commonly originates from one of the adrenal glands but it can also develop in the nerve tissues located in the neck, chest, abdomen and pelvis (2). Common treatments for neuroblastoma include intensive chemotherapy, surgery, radiotherapy, stem cell transplantation and immunotherapy (3-5). Low-risk patients can be cured via surgery, while intermediate and high-risk patients require intensive chemotherapy and/or other treatments (4). Vincristine (VCR), an alkaloid extracted from Catharanthus roseus, is frequently used in combination chemotherapy (6). For example, VCR is used together with topotecan for the treatment of advanced bilateral intraocular retinoblastoma (7). It is also used together with carboplatin for the treatment of children with newly diagnosed progressive low-grade gliomas (8).

In contrast to normal somatic cells, cancer cells exhibit an uncontrolled cell cycle and decreased apoptosis (9). Most chemotherapeutic agents used in the clinic target those two features of cancer cells, inducing their cell cycle arrest and apoptosis. For example, it has been demonstrated that combined treatment with VCR and cisplatin, another commonly used anticancer agent, induced apoptosis of the human retinoblastoma cell lines Y79 and WERI-Rb1, in a dose-dependent manner (10). In acute lymphoblastic leukemia cells, VCR induced apoptosis through activation of caspase- 3 and -9 (11). Other anticancer drugs such as baicalein led to cell cycle arrest at the $\mathrm{S}$ phase by downregulating cell cycle factors including CDK-4, cyclin B1 and D1 in human lung squamous carcinoma $\mathrm{CH} 27$ cells (12). Similarly, VCR, as an anti-tubulin compound, can also lead to cell cycle arrest at the $\mathrm{G}_{2} / \mathrm{M}$ phase by promoting microtubule depolymerization in many tumor cell lines (13). However, despite the studies demonstrating the anti-tubulin and apoptotic effect of VCR on cancer cells, the mechanism involved in the VCR-induced cell death in neuroblastoma cells is still not clear. Consequently, the application of VCR in chemotherapies, for neuroblastoma and lymphoma, still requires a high dosage resulting in high toxicity $(14,15)$.

The SH-SY5Y cell line originates from human neuroblastoma. It contains many features representing dopaminergic neurons (16). SH-SY5Y cells can also be induced to differentiate into mature neurons (16), which exhibit a distinct morphology and are easily detected (16). Therefore, in the 
Table I. Primers used in the RT-PCR reactions.

\begin{tabular}{|c|c|c|}
\hline Gene & Primer sequences & Length (bp) \\
\hline Cyclin B & $\begin{array}{ll}\text { Forward } & \text { 5'-TCGAAAGTGTCGCATCAAACT-3' } \\
\text { Reverse } & \text { 5'-CACAGAAGATGTGAGAGCAGG-3' }\end{array}$ & 65 \\
\hline Cyclin D & $\begin{array}{l}\text { Forward 5'-TCCTCCAGGCTCTAGGCTATC-3' } \\
\text { Reverse } 5 \text { '-CCTAAAACCTCTAGGAGCGTCT-3' }\end{array}$ & 136 \\
\hline Caspase 9 & $\begin{array}{ll}\text { Forward 5'-CACTTCCCCTGAAGACGAGTC-3' } \\
\text { Reverse } & \text { 5'-GTGGGCAAACTAGATATGGCG-3' }\end{array}$ & 111 \\
\hline Caspase 3 & $\begin{array}{l}\text { Forward 5'-CATGGAAGCGAATCAATGGACT-3' } \\
\text { Reverse } 5 \text { '-CTGTACCAGACCGAGATGTCA-3' }\end{array}$ & 139 \\
\hline GAPDH & $\begin{array}{l}\text { Forward 5'-AAGGTGAAGGTCGGAGTCAAC-3' } \\
\text { Reverse 5'-GGGGTCATTGATGGCAACAATA-3' }\end{array}$ & 102 \\
\hline
\end{tabular}

present study we used the SH-SY5Y cell line to analyze the impact of VCR on the cell cycle and changes in apoptosis. We also investigated the expression of apoptotic and cell cycle-related factors following VCR treatment. We aimed to clarify the mechanisms involved in the anticancer function of VCR and provide important references for VCR application in neuroblastoma chemotherapy.

\section{Materials and methods}

Cell culture. The human neuroblastoma cell line SH-SY5Y was purchased from the China Center for Type Culture Collection. Cells were cultured in H-DMEM medium containing $10 \% \mathrm{FBS}$ at $37^{\circ} \mathrm{C}$ with $5 \% \mathrm{CO}_{2}$.

MTT assay measurement of cell proliferation. SH-SY5Y cells at a logarithmic phase were seeded in 96-well plates (at $2 \times 10^{6} / \mathrm{l}$ ) and incubated for $12 \mathrm{~h}$ until cells formed a monolayer. Wells were randomly chosen for treatment groups and a control group. For the treatment groups, cells were incubated with $200 \mu \mathrm{l}$ of cell culture medium containing 0.001, 0.01, 0.1, 1 or $10 \mu \mathrm{M}$ of VCR (Sigma-Aldrich, St. Louis, MO, USA). In the control group, cells were grown in $200 \mu \mathrm{l}$ cell culture medium only. Cells were incubated for another 24,48 and $72 \mathrm{~h}$ and then $20 \mu \mathrm{l}$ of $5 \mathrm{~g} / \mathrm{l} \mathrm{MTT}(0.1 \mathrm{mg} / \mathrm{l}$ final concentration) was added to each well. After $4 \mathrm{~h}$ of incubation, the cell culture supernatant was removed, $150 \mu \mathrm{l}$ of DMSO was added to each well and the plate was shaken for $10 \mathrm{~min}$. The absorbance of each well was detected at $490 \mathrm{~nm}$ ( $A$ value) on an ELISA plate reader. The growth inhibition rate of VCR-treated cells was calculated as: Growth inhibition rate $\%=$ [(average $A$ value of control group - average $A$ value of VCR-treated group)/average $A$ value of control group] x $100 \%$. This experiment was performed in triplicates.

Flow cytometric measurement of the cell cycle distribution. SH-SY5Y cells were seeded in 6-well plates (at $2 \times 10^{6} / \mathrm{ml}$ ) and incubated for $24 \mathrm{~h}$ until they were treated with $0.1 \mu \mathrm{M}$ VCR for 6, 12, 18 and $24 \mathrm{~h}$. Non-treated cells at $0 \mathrm{~h}$ were used as the control group. Cells were washed twice with ice-cold PBS and fixed with 70\% ice-cold ethanol. After centrifuga- tion, $100 \mathrm{mg} / 1 \mathrm{RNase}$ and $5 \mathrm{~g} / \mathrm{l}$ propidium iodide (both purchased from Sigma-Aldrich) were added to each tube, and cells were stained in the dark for $30 \mathrm{~min}$. Detection of cell cycle distribution was then performed on a BD FACSCalibur. FCS Express Version 3.0 software was used to analyze the data.

Immunofluorescent staining measurement of the mitotic index and apoptosis. SH-SY5Y cells were grown on coverslips inside the wells of 6 -well plates and were treated with $0.1 \mu \mathrm{M}$ VCR for $6,12,18$ and $24 \mathrm{~h}$. Non-treated cells at $0 \mathrm{~h}$ were used as the control group. Cells were incubated in warm PHEM solution at $37^{\circ} \mathrm{C}$ for $1 \mathrm{~min}$, permeabilized with $0.1 \%$ Triton X-100 for $1 \mathrm{~min}$ and fixed with $3.7 \%$ formaldehyde for $15 \mathrm{~min}$ at $37^{\circ} \mathrm{C}$. Cells were then washed in PBS and stained for $20 \mathrm{~min}$ with $20 \mu \mathrm{l}$ of Hoechst 33342 (final concentration: $10 \mathrm{~g} / \mathrm{l}$; Sigma-Aldrich). After washing with TBST, cells were incubated with FITC-labeled anti- $\alpha$-tubulin antibody (1:50 dilution; Sigma-Aldrich) for $1 \mathrm{~h}$ at $37^{\circ} \mathrm{C}$. After another TBST wash, fluorescent mounting media were added and the slides were sealed. Under a fluorescence microscope, chromatin agglutination, the number of mitotic cells and the number of apoptotic cells were detected or calculated using Image-Pro Plus 6.0 software. On each slide, 5 fields were chosen randomly, and the number of mitotic cells was counted. The mitotic index (MI) was calculated using the following equation: $\mathrm{MI}=$ number of mitotic cells/total number of cells (17-19).

Real-time (RT)-PCR measurement of caspase-3 and -9, cyclin $B$ and D mRNA expression. Cells were seeded and treated as described previously. Total RNA was extracted using the TRIzol reagent (Invitrogen Life Technologies, Carlsbad, CA, USA) and cDNA was synthesized using the PrimeScript $^{\mathrm{TM}}$ RT kit (TransGen Biotech, Beijing, China) according to the respective manufacturers' instructions. The primers used in the RT-PCR reactions are listed in Table I. The total reaction volume was $20 \mu \mathrm{l}$ including $1 \mu \mathrm{l}$ forward primer, $1 \mu \mathrm{l}$ reverse primer, $1 \mu \mathrm{l}$ cDNA, $4 \mu \mathrm{l}$ SYBR-Green PCR master mix (Roche Diagnostics Corporation, Roche Applied Science, Basel, Switzerland) and $13 \mu \mathrm{lddH_{2 }} \mathrm{O}$. The 


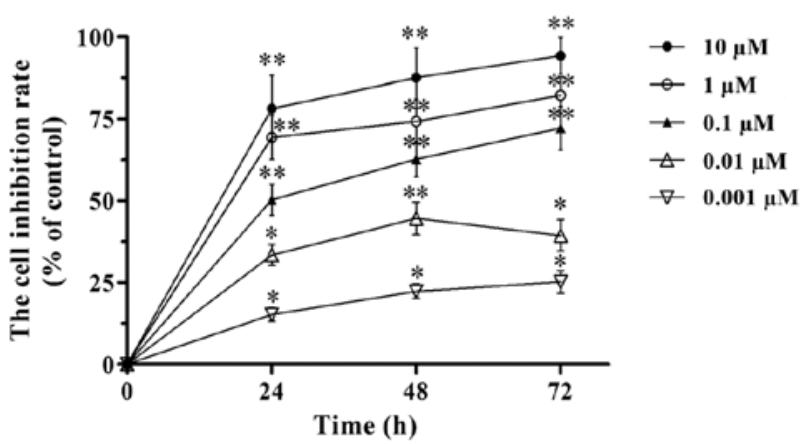

Figure 1. Inhibition of SH-SY5Y cell proliferation by VCR. SH-SY5Y cells were treated with the indicated concentrations of VCR for $0,24,48$ and $72 \mathrm{~h}$ and the proliferation was measured using the MTT assay. ${ }^{*} \mathrm{P}<0.05,{ }^{* *} \mathrm{P}<0.01$ vs. control group (0 h).

following program was used in all reactions: step 1,1 cycle at $95^{\circ} \mathrm{C}$ for $10 \mathrm{~min}$; step 2,45 cycles of $94^{\circ} \mathrm{C}$ for $10 \mathrm{sec}, 60^{\circ} \mathrm{C}$ for $15 \mathrm{sec}$ and $72^{\circ} \mathrm{C}$ for $15 \mathrm{sec}$. Fluorescence signal was collected at each cycle in step 2. All RT-PCR reactions were performed in triplicates. Data were analyzed according to the instruction manual of the Roche LightCycler 2.0 detection system. First, $\Delta \mathrm{Ct}=\mathrm{Ct}_{\mathrm{Gene}}-\mathrm{Ct}_{\mathrm{GAPDH}}$. Then, $\Delta \Delta \mathrm{Ct}=\Delta \mathrm{Ct}$ treated $-\Delta \mathrm{Ct}$ control. Lastly, $2^{-\Delta \Delta \mathrm{Ct}}$ was calculated as the relative mRNA expression of the target genes.

Western blot detection of caspase-3 and -9 , cyclin B and D protein expression. Cells were seeded and treated as described previously. Cells were washed twice in PBS and lysed in lysis buffer [50 mM Tris- $\mathrm{HCl}(\mathrm{pH} \mathrm{7.4);150} \mathrm{mM}$ $\mathrm{NaCl} ; 1 \mathrm{mM}$ ethylene diamine tetra-acetic acid (EDTA); $5 \%(\mathrm{v} / \mathrm{v}) \beta$-mercaptoethanol; $1 \%$ Nonidet P (NP)-40; $0.25 \%$ sodio deoxycholate; $5 \mu \mathrm{g} / \mathrm{ml}$ leupeptin; $5 \mu \mathrm{g} / \mathrm{ml}$ aprotinin; $0.2 \mathrm{mM}$ phenylmethyl sulfonyl fluoride (PMSF)] and incubated on ice for $60 \mathrm{~min}$. Cell lysates were centrifuged at $12,000 \mathrm{x} \mathrm{g}$, the supernatants were collected and the protein concentration was measured. Protein $(50 \mu \mathrm{g})$ was loaded from each sample on SDS-PAGE using a $12 \%$ running gel. Separated proteins were then transferred to PVDF membranes and blocked with $5 \%$ skim milk for $2 \mathrm{~h}$ at $37^{\circ} \mathrm{C}$. Blots were then incubated with primary antibodies (all rabbit IgG) against caspase-3 and -9 (both at a 1:1,000 dilution; purchased from Epitomics, Burlingame, CA, USA), cyclin B (1:50 dilution), cyclin D (1:200 dilution; both purchased from Thermo Fisher Scientific, Fremont, CA, USA) or $\beta$-actin (1:200 dilution; Santa Cruz Biotechnology, Inc., Santa Cruz, CA, USA) overnight at $4^{\circ} \mathrm{C}$. After washing in TBST for $3 \times 15 \mathrm{~min}$, the blots were incubated with HRP-labeled rabbit IgG (1:4,000 dilution; KPL, Gaithersburg, MD, USA) for $2 \mathrm{~h}$ at $37^{\circ} \mathrm{C}$. They were washed again in TBST for $3 \times 15 \mathrm{~min}$, exposed and developed to X-ray films. BandScan 5.0 software was used for protein densitometry measurements ( $A$ value).

Statistical analysis. The SPSS 13.0 software was used for data analysis. The t-test was used in the comparison between 2 groups and one-way ANOVA in the comparison between more groups. Results are presented as means $\pm \mathrm{SE} . \mathrm{P}<0.05$ was considered to indicate a significant difference.

\section{Results}

VCR inhibits the proliferation of SH-SY5Y cells. We investigated the impact of VCR on SH-SY5Y cell proliferation by the MTT assay. Our results revealed that VCR inhibited the proliferation of SH-SY5Y cells (Fig. 1). The inhibitory effect increased with the dose of VCR (from 0.001 to $10 \mu \mathrm{M}$ ). Under the same VCR dose, the inhibitory effect on cell proliferation increased with the time of treatment $(24,48$ and $72 \mathrm{~h}$ time points). Hence, the inhibition of SH-SY5Y cell proliferation by VCR was dose- and time-dependent. According to the MTT assay, the $\mathrm{IC}_{50}$ of VCR in SH-SY5Y cells was $0.113 \pm 0.012,0.078 \pm 0.009$ and $0.051 \pm 0.008 \mu \mathrm{M}$ at 24,48 and $72 \mathrm{~h}$, respectively. We therefore chose $0.1 \mu \mathrm{M}$ of VCR as the treatment dose in the following experiments.

VCR induces SH-SY5Y cell cycle arrest at the $G_{2} / M$ phase. We analyzed the cell cycle distribution of VCR-treated SH-SY5Y cells by flow cytometry. Cells were treated with $0.1 \mu \mathrm{M}$ of VCR for $6,12,18$ and $24 \mathrm{~h}$. The percentage of $\mathrm{G}_{0} / \mathrm{G}_{1}$ phase cells decreased gradually with time, from $76.26 \pm 9.05 \%$ at $6 \mathrm{~h}$ to $16.46 \pm 2.99 \%$ at $24 \mathrm{~h}$, with that of the group treated for $24 \mathrm{~h}$ being significantly lower $(\mathrm{P}<0.01)$ than that in the control group $(84.83 \pm 9.72 \%)$ (Fig. 2). Concomitantly, the percentage of $\mathrm{G}_{2} / \mathrm{M}$ phase cells increased gradually from $20.60 \pm 4.32 \%$ at $6 \mathrm{~h}$ to $72.34 \pm 9.44 \%$ at $18 \mathrm{~h}$, with the percentage in the group treated for $18 \mathrm{~h}$ being significantly higher $(\mathrm{P}<0.01)$ than in the control group $(13.28 \pm 3.76 \%)$. Furthermore, the percentage of cells present at the apoptotic phase (sub- $\mathrm{G}_{1}$ phase) increased from $5.75 \pm 2.74 \%$ at $6 \mathrm{~h}$ to $21.25 \pm 4.36 \%$ at $24 \mathrm{~h}$, with the percentage of cells in the $24 \mathrm{~h}$ treated group being significantly higher $(\mathrm{P}<0.01)$ than that in the control group $(3.47 \pm 1.46 \%)$. These data suggest that VCR induces apoptosis of SH-SY5Y cells following cell cycle arrest at the $\mathrm{G}_{2} / \mathrm{M}$ phase.

VCR induces mitotic arrest of SH-SY5Y cells. Anti-tubulin compounds act by disrupting spindle integrity and activating the mitotic checkpoint, which leads to cell cycle arrest at the M phase and eventually apoptosis (20). In order to confirm whether VCR induces SH-SY5Y cell cycle arrest at the $M$ phase, we performed immunofluorescence microscopy for $\alpha$-tubulin and DNA in VCR-treated and non-treated cells, determined the number of cells at the $M$ phase and calculated the respective mitotic index (MI). Staining with FITC-labeled $\alpha$-tubulin antibody and Hoechst 33342, revealed an evenly distributed microtubule network in green and blue-stained nuclei in untreated SH-SY5Y cells. On the contrary, VCR-treated SH-SY5Y cells exhibited distinct changes in the microtubular structure, showing an accumulation of microtubules close to the nuclei, concomitant with a dramatic decrease in microtubule density in the rest of the cytoplasm (Fig. 3A). This indicates that VCR treatment disrupted the correct assembling of tubulin in these cells, caused cell cycle arrest at the $M$ phase and premature termination of mitosis. In the presence of VCR, the number of cells in the $\mathrm{M}$ phase increased with time, from a MI of $0.25 \pm 0.05$ at $6 \mathrm{~h}$ to $0.71 \pm 0.08$ at $18 \mathrm{~h}$, both being significantly higher than that in the control group (Fig. 3B) $(\mathrm{P}<0.05, \mathrm{P}<0.01)$. 

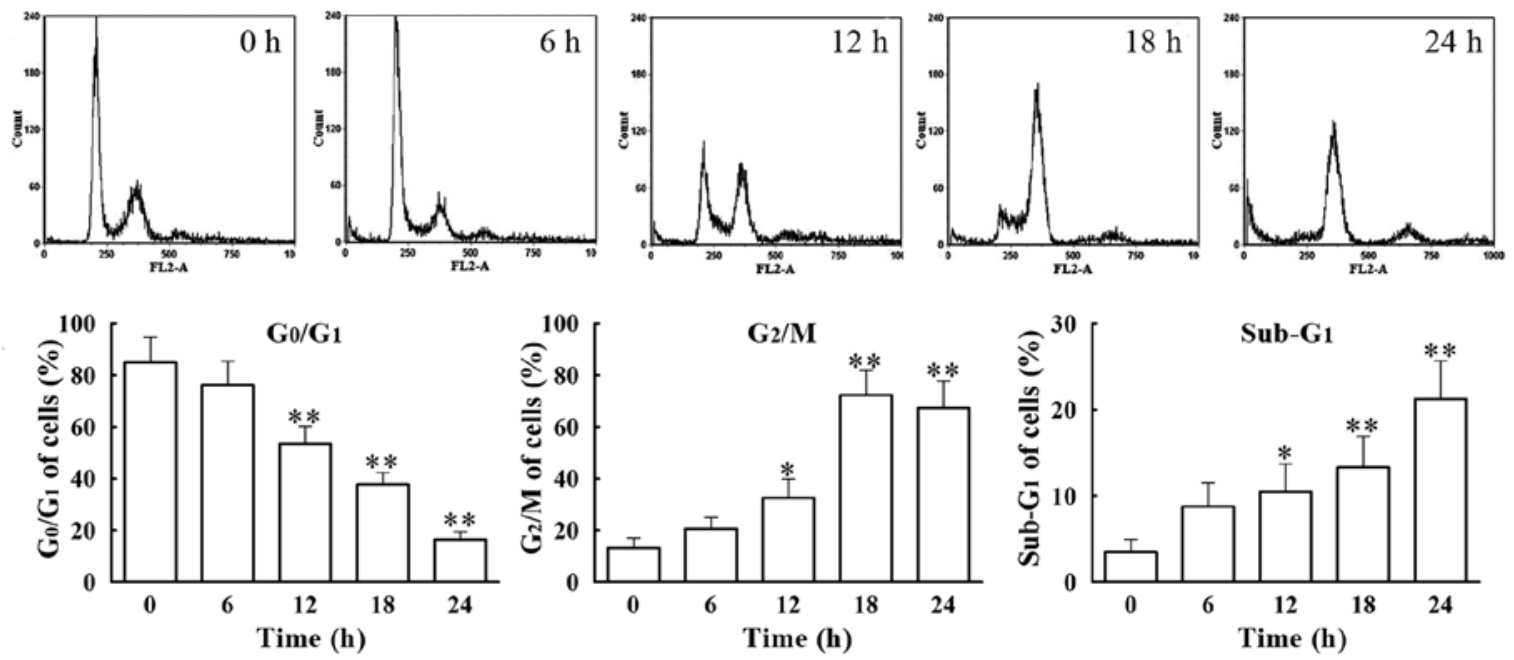

Figure 2. Changes in SH-SY5Y cell cycle distribution induced by VCR. SH-SY5Y cells were treated with $0.1 \mu \mathrm{M}$ of VCR for $0,6,12,18$ and $24 \mathrm{~h}$ and their cell cycle was analyzed by flow cytometry after propidium iodide staining. ${ }^{*} \mathrm{P}<0.05,{ }^{* * *} \mathrm{P}<0.01$ vs. control group $(0 \mathrm{~h})$.
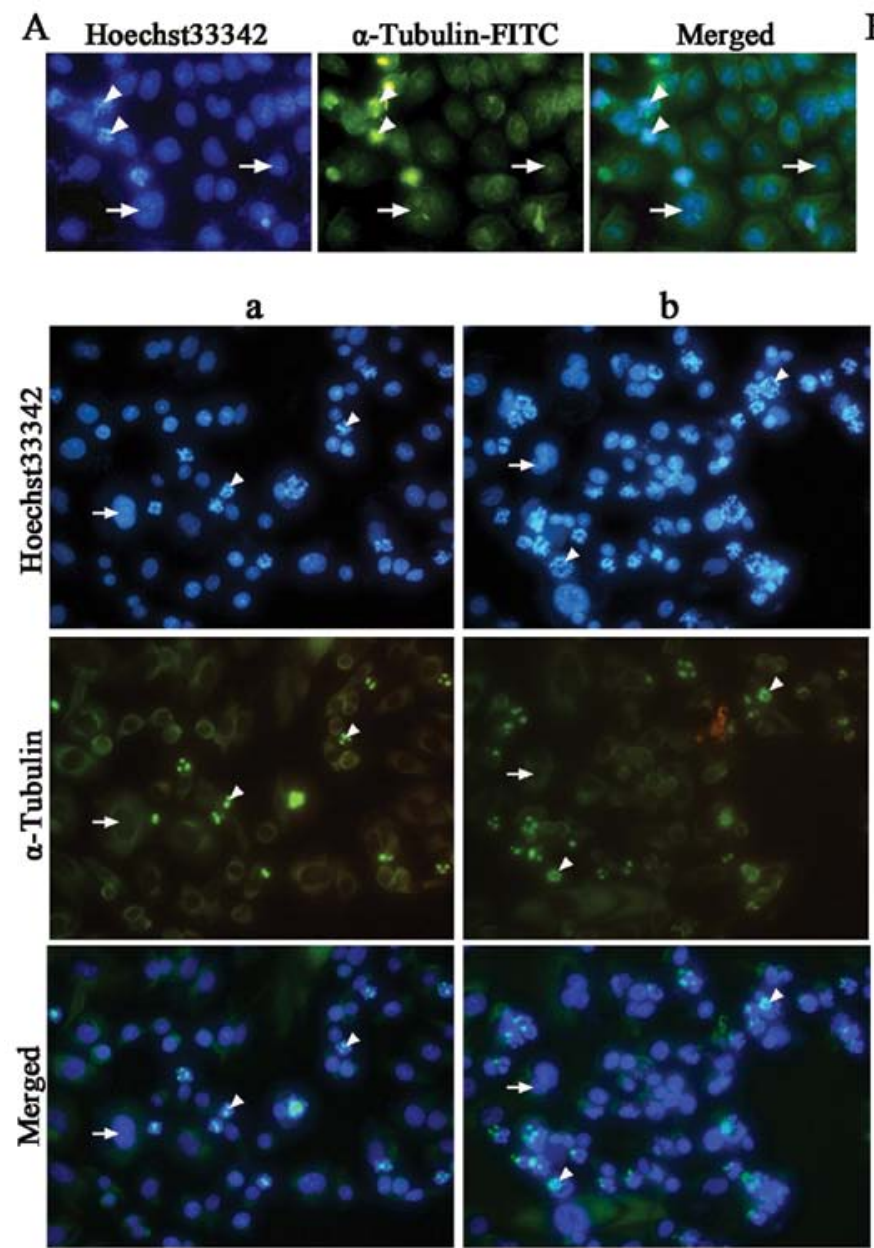

B

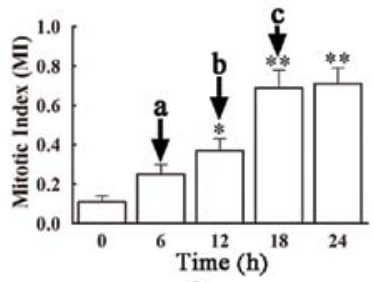

C
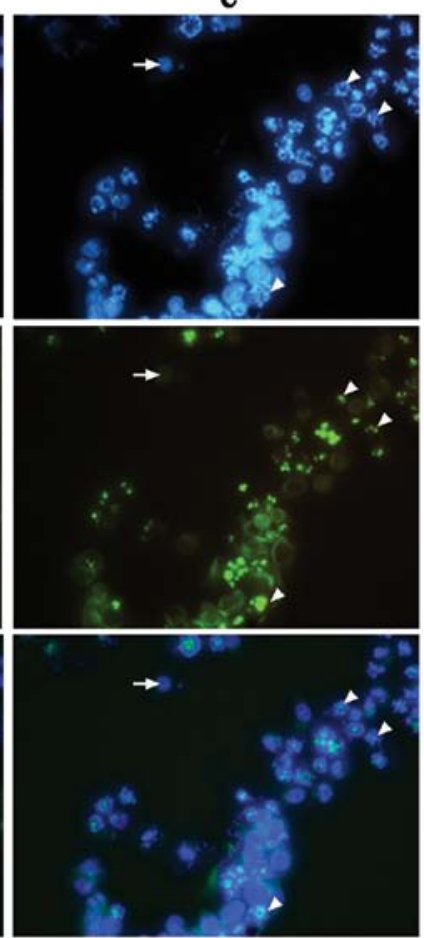

Figure 3. Induction of SH-SY5Y mitotic arrest by VCR. (A) SH-SY5Y cells were treated with $0.1 \mu \mathrm{M}$ of VCR for 0,6 , 12 , 18 or 24 h, stained with Hoechst 33342 and $\alpha$-tubulin. (B) The mitotic index was then calculated and representative images at 3 defined points are shown (a-c). ${ }^{*} \mathrm{P}<0.05$, ${ }^{* *} \mathrm{P}<0.01$ vs. control group $(0 \mathrm{~h})$. The arrows in A and B indicate interphase cells and the arrowheads mitotic cells.

VCR affects the $m R N A$ expression of cyclin $B$ and $D$, caspase-3 and -9 in SH-SY5Y cells. Based on the above findings, we then analyzed by RT-PCR (by the relative quantification method, $2^{-\Delta \Delta C t}$ the mRNA expression of two apoptotic (caspase-3 and -9) and two cell cycle (cyclin B and D) regulators (Fig. 4). Our results showed that treatment with $0.1 \mu \mathrm{M}$ of VCR dramatically increased the mRNA expression of cyclin B, caspase- 9 and -3 , while decreasing the mRNA expression of 
$\mathrm{A}$

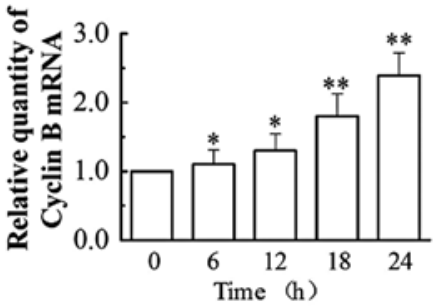

$\mathrm{C}$

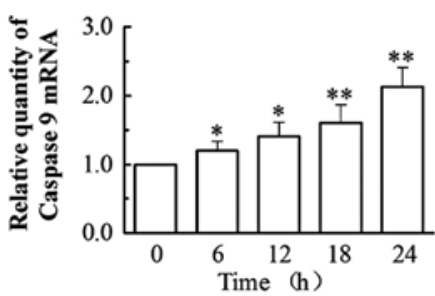

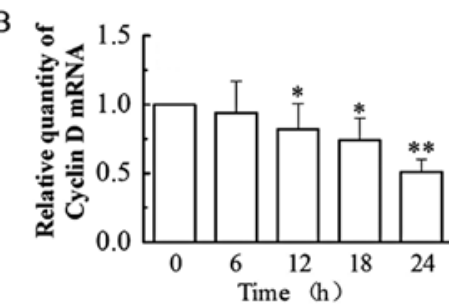

$\mathrm{D}$

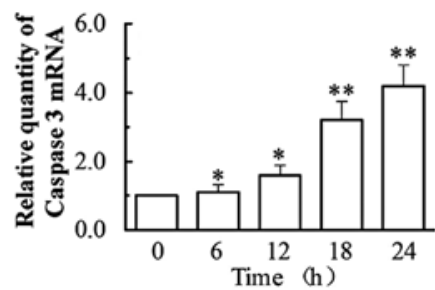

Figure 4. Changes in the mRNA levels of (A) cyclin B, (B) cyclin D, (C) caspase-9 and (D) caspase-3 in SH-SY5Y cells induced by VCR. SH-SY5Y cells were treated with $0.1 \mu \mathrm{M}$ of VCR for $0,6,12,18$ and $24 \mathrm{~h}$, total RNA was extracted and analyzed by RT-PCR. The results presented are relative to GAPDH mRNA expression. ${ }^{*} \mathrm{P}<0.05,{ }^{* *} \mathrm{P}<0.01$ vs. control group $(0 \mathrm{~h})$.

A

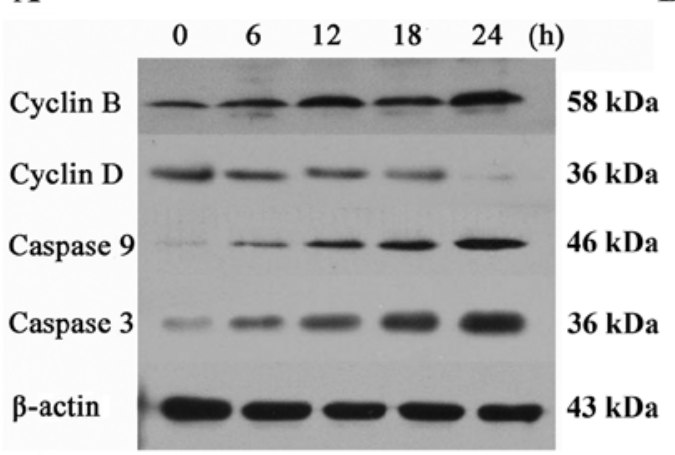

B
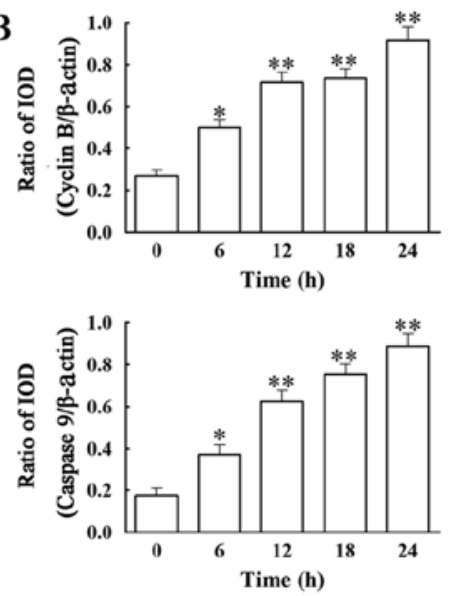
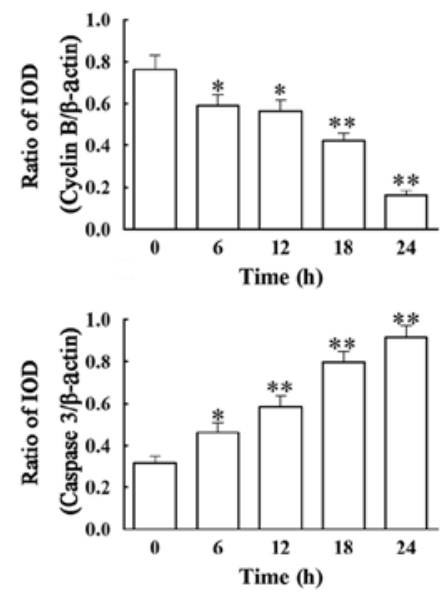

Figure 5. Changes in the protein levels of cyclin B and D, caspase-3 and -9 in SH-SY5Y cells induced by VCR. SH-SY5Y cells were treated with $0.1 \mu \mathrm{M}$ of VCR for $0,6,12,18$ and $24 \mathrm{~h}$, total protein was extracted, analyzed by (A) western blot analysis and (B) quantified in relation to $\beta$-actin. ${ }^{*} \mathrm{P}<0.05,{ }^{* *} \mathrm{P}<0.01$ vs. control group $(0 \mathrm{~h})$.

cyclin D. At $24 \mathrm{~h}, \mathrm{VCR}$ increased the mRNA levels of cyclin B by 2.4 -fold, caspase- 9 by 2.1 -fold and caspase- 3 by 4.2 -fold (all $\mathrm{P}<0.01$ ), while it decreased cyclin $\mathrm{D}$ mRNA expression to $51.21 \%$ of that of the control group $(\mathrm{P}<0.01)$.

VCR affects the protein expression of cyclin B and D, caspase-3 and -9 in SH-SY5Y cells. We next addressed whether the mRNA changes in the 4 regulators were observed at the protein level. Western blot analysis revealed that treatment with $0.1 \mu \mathrm{M}$ of VCR induced a significant increase in protein expression of cyclin B, caspase-3 and -9 and a significant decrease in that of cyclin $\mathrm{D}$, when compared with the control group (Fig. 5) (all $\mathrm{P}<0.01)$. These results are in agreement with the changes in the mRNA expression of the corresponding molecules.

\section{Discussion}

Neuroblastoma is the most common extracranial solid tumor of childhood. The survival rate of children with this disease is only $15 \%$ (21). It is highly heterogeneous and can be classified into 3 risk categories from low to high $(2,4)$. Due to the fact that most low-risk patients can be cured through surgery (4), most neuroblastoma studies are focused on intermediate- and high-risk patients. A clinical study found that short duration and low dosage of combined chemotherapy can lead to a similar curative effect, with a 3-year overall survival rate as high as $96 \pm 1 \%$ and a 3 -year event-free survival as high as $88 \pm 2 \%$, when compared with a long period and high dosage chemotherapy using the same anticancer agents (14). Among high-risk pediatric patients, another clinical study demonstrated that combined chemotherapy and stem cell transplantation can markedly improve the 3-year overall survival rate compared to chemotherapy alone (21). VCR is often used in intensive chemotherapy to treat pediatric patients with advanced neuroblastoma $(22,23)$. However, the mechanisms involved in VCR-induced cell death in this disease are still not clear. High doses of VCR can lead to drug resistance and potential side effects $(14,24)$. Therefore, in the present study we used a human neuroblastoma cell line, 
SH-SY5Y, to investigate the impact of a large range of VCR doses $(0.001-10 \mu \mathrm{M})$ on SH-SY5Y cell cycle and apoptosis, as well as the underlying mechanisms. We demonstrated for the first time that a low dose of VCR $(0.1 \mu \mathrm{M}$, determined by the $\mathrm{IC}_{50}$ value calculated through MTT assay measurement of the impact of different VCR doses on SH-SY5Y cell proliferation) induces mitotic arrest and apoptosis of SH-SY5Y cells.

VCR is a microtubule-interfering compound and thereby a cell cycle-specific agent. VCR disrupts the formation of mitotic spindles and forces cell cycle arrest at the $\mathrm{M}$ phase. Our results indicate that VCR upregulates the expression of cyclin B and downregulates the expression of cyclin D in SH-SY5Y cells. Cyclin B is a mitosis-promoting factor and in normal somatic cells its expression peaks at the $\mathrm{G}_{2}-\mathrm{M}$ transition (25). In contrast, cyclin $\mathrm{D}$ promotes $\mathrm{G}_{1}-\mathrm{S}$ transition (25). The upregulation of cyclin B by VCR may lead to the observed increased number of cells at the $\mathrm{M}$ phase. The downregulation of cyclin $\mathrm{D}$ is not sufficient to drive the cells to progress from the $M$ phase into $G_{0} / G_{1}$, resulting in a cell cycle arrest at the $\mathrm{M}$ phase. At the $\mathrm{G}_{2}-\mathrm{M}$ transition, the DNA damage checkpoint is an important control mechanism in eukaryotic cells, ensuring a DNA repair opportunity before entering into mitosis (26). When VCR induces cell cycle arrest at the $\mathrm{M}$ phase, the self-repair mechanism will allow some cells to pass the cell cycle checkpoint after DNA repair. However, since most cells are not able to pass that checkpoint, there is activation of apoptotic signaling pathways, leading cells to apoptosis (27).

VCR can affect cellular metabolism, inhibit proliferation and induce apoptosis in many types of tumors (28-30). Our results show that VCR induces apoptosis in SH-SY5Y cells through a mechanism involving activation of caspase-3 and -9. The activation of caspase family proteins plays a key role in apoptosis. An inadequate caspase activity is usually observed in neuroblastoma and it is an important factor leading to cancer severity as well as to the development of drug resistance (31). Caspases are usually synthesized and maintained as inactive proenzymes (32). Apoptotic signals can activate the caspase cascade, among which caspase- 3 and -9 are the key caspase proteins. Caspase-3 is an effector or 'executioner', while caspase- 9 is an initiator caspase (32). Caspase-9 can directly or indirectly activate the downstream caspase-3, as well as endonuclease $\mathrm{G}$, which further leads to DNA fragmentation (32). A previous study has suggested that because the peripheral nervous system relies on caspase- 3 for induction of apoptosis, this caspase is expected to be a target gene in the treatment of peripheral nervous system injuries (33). Our study revealed that during VCR-induced SH-SY5Y apoptosis, the expression of caspase-3 and -9 dramatically increased with time. Upregulation of both caspase-3 and -9 can disrupt mitochondrial membrane integrity, leading to the release of cyctochrome c, which induces apoptosis. Caspase- 3 and -9 have also been reported to be able to specifically digest ATPase $4 \mathrm{~b}$ isoform and disrupt the function of calcium pumps, leading to intracellular calcium overload and apoptosis (34).

In conclusion, our study suggests that a low dose of VCR can induce cell cycle arrest at the M phase and eventually apoptosis in SH-SY5Y neuroblastoma cells. This may result from regulation of the expression of cell cycle- related proteins, cyclin $\mathrm{B}$ and $\mathrm{D}$, as well as apoptotic factors including caspase- 3 and -9 by VCR. These data provide reliable evidence for the application of VCR in neuroblastoma chemotherapy.

\section{Acknowledgements}

This study was supported by an NFSC grant (no. 30872668) and the Medical College of Chinese People's Armed Police Forces grant (WYM201015, WYM201109).

\section{References}

1. Dome JS, Rodriguez-Galindo C, Spunt SL and Santana V: Pediatric solid tumors. In: Clinical Oncology. Abeloff MD, Armitage JO, Niederhuber JE, Kastan MB and McKenna WG (eds). 4th edition. Churchill Livingstone Elsevier, Philadelphia, PA, pp2661-2722, 2008

2. Maris JM, Hogarty MD, Bagatell R and Cohn SL: Neuroblastoma. Lancet 369: 2106-2120, 2007.

3. Fish JD and Grupp SA: Stem cell transplantation for neuroblastoma. Bone Marrow Transplant 41: 159-165, 2008.

4. Haase GM, Perez C and Atkinson JB: Current aspects of biology, risk assessment, and treatment of neuroblastoma. Semin Surg Oncol 16: 91-104, 1999.

5. Johnson E, Dean SM and Sondel PM: Antibody-based immunotherapy in high-risk neuroblastoma. Expert Rev Mol Med 9: 1-21, 2007.

6. Coderch C, Morreale A and Gago F: Tubulin-based structureaffinity relationships for antimitotic Vinca alkaloids. Anticancer Agents Med Chem 12: 219-225, 2012.

7. Qaddoumi I, Billups CA, Tagen M, et al: Topotecan and vincristine combination is effective against advanced bilateral intraocular retinoblastoma and has manageable toxicity. Cancer: Apr 19, 2012 (Epub ahead of print).

8. Packer RJ, Ater J, Allen J, et al: Carboplatin and vincristine chemotherapy for children with newly diagnosed progressive low-grade gliomas. J Neurosurg 86: 747-754, 1997.

9. Knudson AG: Two genetic hits (more or less) to cancer. Nat Rev Cancer 1: 157-162, 2001.

10. Conway RM, Madigan MC, Billson FA and Penfold PL: Vincristine- and cisplatin-induced apoptosis in human retinoblastoma. Potentiation by sodium butyrate. Eur J Cancer 34: 1741-1748, 1998.

11. Groninger E, Meeuwsen-De Boer GJ, De Graaf SS, Kamps WA and De Bont ES: Vincristine-induced apoptosis in acute lymphoblastic leukaemia cells: A mitochondrial controlled pathway regulated by reactive oxygen species? Int J Oncol 21: 1339-1345, 2002.

12. Lee HZ, Leung HW, Lai MY and Wu CH: Baicalein induced cell cycle arrest and apoptosis in human lung squamous carcinoma CH27 cells. Anticancer Res 25: 959-964, 2005.

13. Blajeski AL, Phan VA, Kottke TJ and Kaufmann SH: G(1) and $\mathrm{G}(2)$ cell-cycle arrest following microtubule depolymerization in human breast cancer cells. J Clin Invest 110: 91-99, 2002.

14. Baker DL, Schmidt ML, Cohn SL, et al: Outcome after reduced chemotherapy for intermediate-risk neuroblastoma. N Engl J Med 363: 1313-1323, 2010.

15. Haim N, Epelbaum R, Ben-Shahar M, Yarnitsky D, Simri W and Robinson E: Full dose vincristine (without 2-mg dose limit) in the treatment of lymphomas. Cancer 73: 2515-2519, 1994.

16. Xie HR, Hu LS and Li GY: SH-SY5Y human neuroblastoma cell line: in vitro cell model of dopaminergic neurons in Parkinson's disease. Chin Med J (Engl) 123: 1086-1092, 2010.

17. Gupta A, Inaba S, Wong OK, Fang G and Liu J: Breast cancerspecific gene 1 interacts with the mitotic checkpoint kinase BubR1. Oncogene 22: 7593-7599, 2003.

18. Madhavan J, Ganesh A and Kumaramanickavel G: Retinoblastoma: from disease to discovery. Ophthalmic Res 40: 221-226, 2008.

19. Singh VK, Zhou Y, Marsh JA, et al: Synuclein-gamma targeting peptide inhibitor that enhances sensitivity of breast cancer cells to antimicrotubule drugs. Cancer Res 67: 626-633, 2007.

20. Jordan MA: Mechanism of action of antitumor drugs that interact with microtubules and tubulin. Curr Med Chem Anticancer Agents 2: 1-17, 2002. 
21. Matthay KK, Villablanca JG, Seeger RC, et al: Treatment of high-risk neuroblastoma with intensive chemotherapy, radiotherapy, autologous bone marrow transplantation, and 13-cis-retinoic acid. Children's Cancer Group. N Engl J Med 341: 1165-1173, 1999.

22. Zoubek A, Holzinger B, Mann G, et al: High-dose cyclophosphamide, adriamycin, and vincristine (HD-CAV) in children with recurrent solid tumor. Pediatr Hematol Oncol 11: 613-623, 1994.

23. Rubie H, Coze C, Plantaz D, et al: Localised and unresectable neuroblastoma in infants: excellent outcome with low-dose primary chemotherapy. Br J Cancer 89: 1605-1609, 2003.

24. Kotchetkov R, Cinatl J, Blaheta R, et al: Development of resistance to vincristine and doxorubicin in neuroblastoma alters malignant properties and induces additional karyotype changes: a preclinical model. Int J Cancer 104: 36-43, 2003.

25. Ford HL and Pardee AB: Cancer and the cell cycle. J Cell Biochem Suppl 32-33: 166-172, 1999.

26. Cuddihy AR and O'Connell MJ: Cell-cycle responses to DNA damage in G2. Int Rev Cytol 222: 99-140, 2003.

27. Kung AL, Zetterberg A, Sherwood SW and Schimke RT: Cytotoxic effects of cell cycle phase specific agents: result of cell cycle perturbation. Cancer Res 50: 7307-7317, 1990.
28. Shi JH, Xu XP, Zhang ZL, Zhang JS, Ge JB and Cheng WY: Inhibition of activation of nuclear factor-kappaB enhanced apoptosis of leukemic cells induced by homoharringtonine. Zhonghua Nei Ke Za Zhi 42: 292-295, 2003 (In Chinese).

29. Shinwari Z, Al-Hindi H, Al-Shail E, et al: Response of medulloblastoma cells to vincristine and lomustine: role of TRKC, CTNNB1 and STK15. Anticancer Res 31: 1721-1733, 2011.

30. Sung KH, Lee EH and Kim YZ: Factors influencing the response to high dose methotrexate-based vincristine and procarbazine combination chemotherapy for primary central nervous system lymphoma. J Korean Med Sci 26: 551-560, 2011.

31. Zhang J, Chatterjee K, Alano CC, Kalinowski MA, Honbo N and Karliner JS: Vincristine attenuates N-methyl-N'-nitro$\mathrm{N}$-nitrosoguanidine-induced poly-(ADP) ribose polymerase activity in cardiomyocytes. J Cardiovasc Pharmacol 55: 219-226, 2010.

32. Salvesen GS: Caspases: opening the boxes and interpreting the arrows. Cell Death Differ 9: 3-5, 2002.

33. Simpson MT, MacLaurin JG, Xu D, et al: Caspase 3 deficiency rescues peripheral nervous system defect in retinoblastoma nullizygous mice. J Neurosci 21: 7089-7098, 2001.

34. Hajnoczky G, Davies E and Madesh M: Calcium signaling and apoptosis. Biochem Biophys Res Commun 304: 445-454, 2003. 